\title{
Penerapan Gerak dan Lagu "Bangun Pagi” dalam Mengembangkan Kemampuan Motorik Kasar Anak Usia 4-5 Tahun Di TK Negeri Pembina 5 Malang
}

\author{
Riza Aprilia Kusuma Wardani*, I Made Seken, Rosyi Damayani Twinsari Maningtyas \\ Universitas Negeri Malang, Jl. Semarang No. 5 Malang, Jawa Timur, Indonesia \\ *Penulis korespondensi, Surel: risha.aprilia73@gmail.com
}

Paper received: 2-2-2021; revised: 20-2-2021; accepted: 27-2-2021

\begin{abstract}
This study aims to find out how much the Motion and Song Application in increasing Rough Motoric Ability of Children aged 4-5 years. this study consisted of two variables, namely: Motion and Song and Rough Motorics. This study uses a classroom action research model from Kemmis and Mc. Taggart with stages of planning, action and observation, reflection and improvement plans. The hypothesis proposed in this study is the Application of Motion and Songs can Improve Rough Motoric Ability of Children Aged 4-5 Years in TK 5 Builder of Malang. The results of the study of the application of motion and song showed that through movement and song activity the development of gross motoric abilities of children aged 4-5 years increased. This is evident from the acquisition of the value of the first cycle of 6.25 percent, 18.75 percent, 37.5 percent in three meetings. Cycle II obtained a value of 56.25 percent, 81.25 percent, 87.5 percent in three meetings.
\end{abstract}

Keywords: motion and song; rough motoric; children aged 4-5 years

\begin{abstract}
Abstrak
Penelitian ini bertujuan untuk mengetahui seberapa besar Penerapan Gerak dan Lagu dalam meningkatkan Kemampuan Motorik Kasar Anak Usia 4-5 tahun. penelitian ini terdiri dari dua variabel yaitu: Gerak dan Lagu dan Motorik Kasar. Penelitian ini menggunakan model penelitian tindakan kelas dari Kemmis dan Mc. Taggart dengan tahapan perencanaan, tindakan dan observasi, refleksi dan perbaikan rencana. Hipotesis yang diajukan dalam penelitian ini adalah Penerapan Gerak dan Lagu dapat Meningkatkan Kemampuan Motorik Kasar Anak Usia 4-5 Tahun di TK NegeriPembina 5 Malang. Hasil penelitian penerapan gerak dan lagu menunjukkan bahwa melalui kehgiatan gerak dan lagu maka perkembangan kemampuan motorik kasar anak usia4-5 tahun meningkat. Hal tersebut terbukti dari perolehan nilai siklus I yaitu 6,25 persen, 18,75 persen, 37,5 persen dalam tiga kali pertemuan. Siklus II diperoleh nilai 56,25 persen, 81,25 persen, 87,5 persen dalam tiga kali pertemuan.
\end{abstract}

Kata kunci: gerak dan lagu; motorik kasar; anak usia 4-5 tahun

\section{Pendahuluan}

Perkembangan pada Anak Usia Dini (AUD) merupakan bagian dari perkembangan manusia secara keseluruhan. Perkembangan motorik menurut Hildayani (2013) adalah perubahan secara progresif pada kemampuan koordinasi saat melakukan gerakan melalui beberapa faktor internal. Anak usia 0-6 tahun memiliki perkembangan yang cepat dalam mempelajari sesuatu yang anak lihat dan dengar. Perkembangan motorik pada AUD merupakan aspek yang penting untuk diberikan stimulus yang tepat. Karena perkembangan tersebut mempengaruhi dalam kehidupan anak seperti pembentukkan rasa percaya diri. Pada masa usia dini terjadinya kematangan fungsi fisik dan psikis yang siap merespon sesuatu yang diberikan oleh lingkungan sekitar. Oleh karena itu stimulasi yang optimal perlu diberikan untuk mengembangkan kemampuan motorik kasar agar anak siap merespon apa yang 
diperolehh dari lingkungan sekitarnya. Sumantri (2005) berpendapat bahwa gerakan motorik kasar adalah kemampuan yang membutuhkan koordinasi sebagian besar bagian tubuh anak dengan melibatkan otot besar. Sejalan dengan pendapat tersebut maka kegiatan motorik kasar dapat dilakukan melalui gerak dan lagu. Kemampuan motorik kasar dapat meliputi unsur kebugaran jasmani. Kemampuan tersebut dapat dikembangkan dengan optimal melalui kegiatan motorik yang tepat dan sesuai dengan kebutuhan.

Berdasarkan observasi di TK Negeri Pembina 5 Kota Malang yang dilakukan pada bulan Agustus 2018 sampai September 2018, peneliti mengobservasi kelompok A2 yang berjumlah 16 anak dan diketahui 9 anak di kelompok A2 belum mendapatkan stimulus yang sesuai untuk mengembangkan fisik motorik kasar mereka. Sebanyak 9 anak diketahui belum mampu melakukan kegiatan fisik motorik yang diberikan oleh guru dengan baik. Kemampuan motorik kasar anak terlihat belum mencapai hasil yang optimal. Anak belum melakukan gerakan yang terkoordinasi dengan baik, gerakan yang dilakukan anak tidak sesuai dengan yang dicontohkan guru, serta tidak terlihat anak melakukan gerakan dengan lentuk, lincah dan gerakan yang melatih keseimbangan.

Berdasarkan pemaparan permasalahan tersebut peneliti memberikan alternatif yang diperlukan yaitu dengan menggunakan gerak dan lagu untuk mengembangkan kemampuan fisik motorik kasar anak kelompok A di TK Negeri Pembina 5 Malang. Pelaksanaan gerak dan lagu dapat disesuaikan dengan karakteristik gerak dan lagu anak dan mengkombinasikan gerakan yang sesuai dengan lirik lagu. Kegiatan motorik dengan gerak dan lagu tidak hanya mengembangkan kemampuan fisik motorik kasar anak tetapi nantinya juga akan mengembangkan keterampilan berbahasa, kepekaan terhadap sebuah lagu, mengembangkan rasa percaya diri pada anak serta menciptakan perasaan senang (Kamtini \& Tanjung, 2005: 133). Kegiatan fisik motorik menggunakan gerak dan lagu sangat dekat dengan anak usia dini. Pembelajaran melalui gerak dan lagu merupakan pembelajaran yang menarik dan termasuk kegiatan belajar sambil bermain dan bermain sambil belajar. Wulandari (2017) menyatakan bahwa dengan mengajarkan kegiatan gerak dan lagu atau menari bersama dapat melatih kecerdasan fisik anak. Melalui kegiatan gerak dan lagu yang disesuaikan dengan karakteristik perkembangan, gerak serta lagu anak maka kemampuan motorik anak dapat mencapai hasil yang optimal.

Kegiatan motorik kasar melalui gerak dan lagu diharapkan dapat mengembangkan kemampuan motorik kasar anak usia 4-5 tahun di TK Negeri Pembina 5 Malang. melalui kegiatan ini juga dapat dijadikan sebagai bahan referensi oleh guru untuk melakukan kegiatan motorik yang menyenangkan dan menarik untuk anak. Berdasarkan pemaparan latar belakang di atas maka akan dilaksanakan penelitian dengan judul "Penerapan Gerak dan Lagu "Bangun Pagi” dalam Mengembangkan Kemampuan Fisik Motorik Kasar pada Kelompok A di TK Negeri Pembina 5 Malang".

\section{Metode}

Penelitian ini menggunakan Penelitian Tindakan Kelas (PTK) dengan model kolaboratif dengan melibatkan satu orang guru sebagai kolaborator. Arikunto (2013) mengemukakan bahwa "penelitian tindakan kelas yang baik adalah apabila dilakukan dalam bentuk kolaborasi”. Model penelitian yang digunakan adalah model yang dikembangkan oleh Kemmis \& MC. Taggart dalam Arikunto (2013). Pendekatan dalam penelitian ini yaitu pendekatan kuanitatif dan kualitatif. Pada pelaksanaan tindakan, peneliti juga mengamati selama 
pelaksanaan kegiatan berlangsung lalu peneliti merefleksi hasil dari rancangan pembelajaran yang telah dibuat terhadap aspek perkembangan yang akan ditingkatkan. Jika hasil dari refleksi menunjukkan peningkatan sesuai dengan yang diharapkan, maka penelitian dianggap selesai. Jika masih belum memenuhi standar ketercapaian yang diharapkan yaitu aspek perkembangan motorik kasar unsur koordinasi, kelentukkan, keseimbangan dan kelincahan belum terlihat pada anak, maka perlu diadakan perbaikan pada pelaksanaan siklus selanjutnya untuk mencapai nilai ketuntasan yang diharapkan

Subjek penelitian ini adalah anak usia 4-5 tahun di TK Negeri Pembina 5 Malang pada tahun ajaran 2018/2019. Anak usia 4-5 tahun atau kelompok A2 terdiri dari 5 anak perempuan dan 11 anak laki-laki. Data yang dihgunakan berupa data aktivitas anak, aktivitas guru, data ketercapaian kemampuan motorik kasar anak, data wawancara, data dokumentasi dan catatan lapangan. Seumber data dalam penelitian ini adalah anak dan guru kelompok A2 TK Negeri Pembina 5 Malang. Anak kelompok A2 menjadi subjek yang diamati oleh peneliti, sedangkan guru sebagai pelaksana tindakan dan teman diskusi dan narasumber serta peran teman sejawat yang membantu mendokumentasikan seluruh kegiatan. Peneliti menggunakan analisis data kuantitatif dan analisis data kualitatif yang meliputi data capaian perkembangan motorik kasar anak sebagai data kuantitatif dan hasil wawancara, catatan aktivitas anak, catatan aktivitas guru serta catatan lapangan sebagai data kualitatif.

Analisis data kualitatif menggunakan tahapan yang dimulai dari pengumpulan data, penyederhanaan data penyajian dan kesimpulan. Semua data kualitatif diperlukan dan dianalisis untuk mendapatkan kesimpulan dari seluruh data yang diperoleh. Adapun data kuantitatif dianalisis dengan menggunakan rumus yang diwujudkan dalam nilai persentase menurut Trianto (2010) sebagai berikut:

Tabel 1. Kriteria ketercapaian kelas

\begin{tabular}{ccc}
\hline Interval Presentasi & Keterangan & Kriteria Nilai \\
\hline $85 \%-100 \%$ & Sangat Tercapai & BSB \\
$75 \%-84 \%$ & Tercapai & BSH \\
$38 \%-74 \%$ & Mulai Tercapai & MB \\
$0 \%-37 \%$ & Belum Tercapai & BB \\
\hline
\end{tabular}

Mengacu pada kriteria yang telah ditentukan maka batas minimal nilai keberhasilan dalam penelitian ini adalah $75 \%$. Persentase ketercapaian kemampuan motorik kasar akan dikatakan tercapai apabila mencapai nila 75\% - 100\%.

\section{Hasil dan Pembahasan}

Observasi awal dilaksanakan oleh peneliti pada bulan Agustus hingga September 2018 di TK Negeri Pembina 5 Malang. Kegiatan pagi yang dilakukan dimulai pukul 07.30 yaitu baris berbaris dan senam mars Pembina di halaman sekolah. Kegiatan senam ini diikuti oleh semua anak mulai kelompok bermain hingga kelompok B. Peneliti berfokus pada unsur kebugaran jasmani yang dapat dikembangkan melalui kegiatan gerak dan lagu dan kegiatan permainan sirkuit yang dilaksanakan di Sekolah. Setelah melakukan pengamatan peneliti mendapati hasil bahwa unsur kebugaran jasmani yang meliputi koordinasi, kelincahan, kelentukkan dan keseimbangan belum berkembang dengan optimal pada sebagian besar anak kelompok A2. Hasil pengamatan pra tindakan yaitu 9 anak dari 16 anak terlihat belum berkembang pada unsur kebugaran jasmani. 
Pelaksanaan siklus I dilaksanakan selama tiga kali pertemuan. Hasil dari pertemuan pertama hingga ketiga menunjukkan hasil yang belum berkembang. Anak belum mampu menirukan gerakan dengan baik sesuai contoh. Hal tersebut disebabkan karena dalam melakukan kegiatan gerak dan lagu diperlukan waktu yang lebih lama untuk mengahfalkan gerakan beserta lagu. Oleh karena itu banyak anak yang belum mencapai hasil perkembangan yang optimal. Adapun persentase perolehan hasil perkembangan motorik kasar pada pertemuan pertama siklus I adalah 6,25\% dengan kategori belum tercapai. Hasil persentase pada pertemuan kedua siklus I adalah $18,75 \%$ dengan kategori belum tercapai. Pertemuan ketiga siklus I mencapai hasil 37,5\% dengan kategori mulai tercapai. Meskipun hingga pertemuan ketiga masih menunjukkan persentase kelas dengan kategori belum tercapai tetapi setiap pertemuan mengalami perubahan dan meningkat. Hal tersebut membuktikan bahwa melalui kegiatan gerak dan lagu dapat meningkatkan kemampuan motorik kasar anak. Akan tetapi hasil akhir dari pertemuan ketiga belum memenuhi standar ketercapaian yang diharapakan.

Berdasarka refleksi pelaksanaan siklus I dengan tiga kali pertemuan maka peneliti dan guru mendiskusikan perbaikan yang akan dilakukan pada siklus II. Adapun perbaikan yang dilakukan adalah: 1) memberikan gerakan intro atau sebelum masuk pada gerakan inti dengan tepuk tangan, berputar dan melompat sebagai variasi dan untuk membangun mood anak agar lebih focus, 2) Perbaikan kedua adalah kegiatan gerak dan lagu dilakukan di dalam kelas untuk menghemat waktu dan agar anak tidak fokus pada permainan yang lainnya.

Pelaksanaan kegiatan motorik dengan gerak dan lagu pada pertemuan pertama siklus II memperoleh persentase ketercapaian kelas sebesar $56,25 \%$ dengan kategori mulai tercapai. Pertemuan kedua pada siklus II mencapai hasil persentase ketercapaian kelas sebesar 81,25\% dengan kategori tercapai. Adapun pertemuan ketiga pada siklus II mencapai hasil persentase ketercapaian kelas sebesar 87,5\% dengan kategori sangat tercapai. Pelaksanaan siklus II telah menunjukkan adanya peningkatan yang signifikan dan hasil yang dicapai telah melebihi standar ketercapaian yang diharapakan yaitu $\geq 75 \%$. Hal yang paling mempengaruhi adalah gerakan yang dilakukan mudah dan berhubungan dengan kegiatan sehari-hari anak, lagu yang dinyanyikan memiliki melodi yang diulang dan lirik mengandung arti dalam kegiatan seharihari yang dekat dengan anak. Melalui gerakan-gerakan koordinasi mata dengan tangan dan kaki, gerakan meliukkan tubuh dan menggoyangkan badan, berjalan lurus dengan merentangkan kedua tangan dan gerakan melompat berpindah tempat anak dapat mengembangkan unsur kebugaran jasmani yang meliputi koordinasi, kelentukkan, kelincahan dan kesimbangan dapat berkembang dengan optimal. Selain itu tidak lepas dari usaha guru yang membimbing dan membantu anak untuk melakukan gerak dan lagu dengan baik. Melihat adanya perubahan dari siklus I hingga siklus II yang signifikan maka dapat disimpulkan bahwa kegiatan motorik menggunakan gerak dan lagu "Bangun Pagi" dapat meningkatkan kemampuan motorik kasar anak usia 4-5 tahun (Kelompok A2) di TK Negeri Pembina 5 Malang.

Peningkatan kemampuan motorik kasar anak usia 4-5 tahun melalui gerak dan lagu dirancang menggunakan indikator yang ditentukan oleh peneliti yaitu: a) Koordinasi, b) Kelentukkan, c) Kelincahan, d) Keseimbangan. Adapun unsur-unsur kebugaran jasmani tersebut juga sesuai dengan yang dikemukakan oleh Wulandari (2017) bahwa "Kegiatan gerak dan lagu atau menari bersama dapat melatih kecerdasan fisik anak. Hal ini disebabkan karena 
kedua kegiatan tersebut menuntut adanya keseimbangan, keselarasan koordinasi gerak dan tubuh, kekuatan dan kelenturan otot ketika bergerak".

Langkah-langkah dalam upaya meningkatkan kemampuan motorik kasar anak melalui gerak dan lagu "Bangun Pagi" adalah 1) membuat lagu dan menentukan gerakan yang sesuai dengan lirik, 2) anak diajak untu keluar kelas, 3) anak membentuk lingkaran dan bergandengan tangan, 4) guru menjelaskan kegiatan gerak dan lagu, 5) guru dan peneliti memberikan contoh gerak dan lagu, 6) guru mencotohkan secara bertahap dan sesuai dengan lirik lagu, 7) gerakan terdiri dari pemanasan, gerakan inti dan gerakan pendinginan, 8) kegiatan dilaksanakan berulang-ulang 4-5 kali.

Sesuai dengan pendapat Wulandari (2017) mengenai langkah-langkah pelaksanaan kegiatan gerak dan lagu yaitu sebagai berikut : 1) Menyesuaikan kondisi psikologis anak, 2) Memilih tema gerak dan lagu, 3) Tema yang dipilih berhubungan lingkungan sekitar anak atau kehidupan sehari-hari anak, 4) Memilih gerakan dengan tingkat kesulitan rendah dan komikal (lucu), 5) Memilih alur dinamik, sedang, lembut dan cepat, 6) Membuat pola lantai gerak dan lagu yang sederhana, 7) Gerak dan lagu dapat dilakukan secara berkelompok, 8) Pendidik menguasai materi gerak dan lagu, 9) Berikan gerakan secara bertahap, 10) Membuat selingan dalam kegiatan gerak dan lagu, 11) Melakukan pengulangan , 12) Membagi porsi pertemuan sesuai dengan kondisi fisik anak, 13) Membuat pentas kecil bersama teman satu kelas, 14) Konsistensi menggunakan properti jika dibutuhkan, 15) Pemilihan busana yang mendukung apabila diperlukan, 16) Tata rias yang sesuai apabila diperlukan.

Pelaksanaan kegiatan gerak dan lagu di lapangan, dengan alokasi waktu 15 menit. Alokasi waktu tersebut digunakan untuk pemanasan pada 5 menit awal, 7 menit gerakan inti dan 3 menit untuk pendinginan dan refleksi. Berdasarkan pengamatan peneliti, guru telah melaksanakan sesuai dengan aturan yang telah disepakati antara peneliti dan guru. Guru menyampaikan di depan anak-anak dengan suara yang keras, intonasi jelas dan ekspresi tersenyum. Hal tersebut dapat menjadi faktor penyemangat anak ketika melakukan kegiatan gerak dan lagu. Guru menjelaskan dimulai dari berjalan keluar kelas dan melakukan pemanasan dengan bentuk lingkaran, lalu masuk pada gerakan inti dan diakhiri dengan pendinginan tarik napas serta refleksi.

Pertemuan pertama pada siklus I anak-anak masih terlihat kesulitan megikuti contoh dari guru dan peneliti. Hingga pertemuan ketiga teradapat 6 dari 16 anak yang belum menghafal gerakan dan lagu yang dicontohkan. Setelah diamati, hal tersebut terjadi karena kegiatan ini memerlukan waktu lebih pada bagian awal yaitu menyiapkan anak untuk keluar kelas. Anak-anak yang berada di luar kelas lebih fokus pada permainan yang ada di luar seperti perosotan, ayunan dan putar-putaran. Sehingga keenam anak tersebut kurang fokus pada guru yang memberikan contoh.

Sehingga pertemuan siklus II peneliti membuat perbaikan yaitu yang pertama membrikan intro di awal sebelum masuk pada pemanasan. Hal tersebut dirasa perlu karena akan membangun mood anak untuk lebih fokus dan melakukan kegiatan gerak dan lagu dengan maksimal. Kedua, dengan melaksanakan kegiatan gerak dan lagu di dalam kelas. Hal tersebut dilakukan agar ketika anak-anak melaksanakan gherak danlagu lebih fokus dan tidak bermain yang lainnya. Setelah peneliti melakukan penelitian selama tiga hari, ternyata mengalami perubahan yang signifikan dari siklus I ke siklus II. Hasil yang diperoleh meningkat dan sesuai dengan standar ketercapaian yang diharapkan oleh peneliti. 
Berdasarkan pemaparan di atas maka dapat dikatakan bahwa melalui kegiatan gerak dan lagu dapat meningkatkan kemampuan motorik kasar anak. Hal tersebut didukung oleh pendapat dari Wulandari (2017) bahwa dengan mengajarkan kegiatan gerak dan lagu atau menari bersama dapat melatih kecerdasan fisik anak. Pelaksanaan siklus I belum mencapai hasil yang optimal dan anak masih merasa kesulitan dengan gerak dan lagu. Anak-anak membutuhkan penyesuaian terlebih dahulu terhadap lagu yang digunakan. Lalu guru mengajarkan gerakan yang dilakukan mengikuti setiap lirik lagu. Fokus anak terganggu karena pelaksanaan kegiatan dilaksanakandi luar kelas, anak lebih senang bermain permainan perosotan, ayunan dan bermain kejar-kejaran dengan teman. Peneliti melakukan perbaikan pada siklus II dengan memberikan gerakan intro berupa tepuk tangan, melompat dan berputar dengan tujuan membangun mood anak. Perbaikan yang kedua adalah melaksanakan kegiatan gerak dan lagu di dalam kelas dengan tujuan anak tidak fokus pada permainan yang lain dan memperhatikan guru.

\section{Simpulan}

Berdasarkan hasil penelitian tentang penerapan gerak dan lagu "Bangun Pagi" untuk meningkatkan kemampuan motorik kasar anak usia 4-5 tahun di TK Negeri Pembina 5 Malang dapat disimpulkan sebagai berikut: 1) Kegiatan gerak dan lagu "Bangun Pagi" dilaksanakan pada awal kegiatan, bertempat di luar kelas dan di dalam kelas sebagai selingan. Gerak dan lagu tidak hanya meningkatan kemampuan motorik kasar tetapi juga aspek perkembangan yang lain, 2) Kegiatan gerak dan lagu mampu meningkatkan kemampuan motorik kasar dengan ketercapaian pada siklus II sebesar 87,5\%,3) Dua anak yang tidak mau mengikuti dengan tertib kegiatan gerak dan lagu belum mampu melakukan seperti anak-anak yang lain. Kedua anak ini memiliki perilaku sangat aktif dan merupakan teman akrab yang membuat mereka tidak mau dipisahkan. Sehingga selalu berdekatan dan bermain bersama.

Melihat dari hasil penelitian pada anak kelompok A2 TK Negeri Pembina 5 Malang, ditemukan 1) fasilitas ruangan yang kurang memadai sebagai tempat belajar yang nyaman dan menyenangkan bagi anak, 2) gerak dan lagu "Bangun Pagi" dapat meningkatkan kemampuan motorik kasar dan kemampuan lainnya, 3) anak cepat merasa bosan, 4) konsentrasi anak yang kurang fokus. Berdasarkan temuan tersebut disampaikan beberapa saran yang membangun agar dapat meningkatkan kualitas peroses belajar mengajar selanjutnya. Berikut adalah saran yang disampaikan: (1) bagi kepala sekolah, pengadaan sarana dan prasarana yang memadai agar semangat belajar anak bertambah. Sehingga mendukung dan memberikan inspirasi bagi guru untuk melakukan kegiatan belajar mengajar; (2) bagi guru, guru dapat memanfaatkan kegiatan gerak dan lagu sebagai variasi kegiatan motorik kasar agar dapat meningkatkan kemampuan motorik kasar anak serta kemampuan yang lainnya; (3) bagi peneliti selanjutnya, sebagai bahan referensi, peneliti selanjutnya agar lebih memperhatikan lokasi pelaksanaan gerak dan lagu karena mempengaruhi konsentrasi. Selain itu pola lantai perlu diperhatikan, karena sebaiknya anak-anak berteman dekat dipisahkan agar tidak mengganggu teman yang lainnya.

\section{Daftar Rujukan}

Arikunto, S. (2013). Penelitian Tindakan Kelas. Jakarta: Bumi Aksara.

Hildayani, R. (2014). Psikologi Perkembangan Anak. Tangerang Selatan. Universitas Terbuka

Kamtini, \& Tanjung, H. W. (2005). Bermain Melalui Gerak dan Lagu Di Taman Kanak- Kanak. Jakarta: Departemen Pendidikan Nasional, Direktorat Jendral Pendidikan tinggi, Direktorat Pembinaan Pendidikan Tenaga Kependidikan dan Ketenagaan Perguruan Tinggi.

Sumantri. (2005). Pengembangan Keterampilan Motorik Anak Usia Dini. Jakarta: Dinas Pendidikan

Trianto. (2010). Model Pembelajaran Terpadu. Jakarta: Bumi Aksara 
Jurnal Pembelajaran, Bimbingan, dan Pengelolaan Pendidikan, 1(2), 2021, 84-90

Wulandari, R. T. (2017). Artikel Dosen: Pembelajaran Olah Gerak Dan Tari Sebagai Sarana Ekspresi Dan Apresiasi Seni Bagi Anak Usia Dini. (http://lib.um.ac.id/index.php/2017/08/01/pembelajaran-olah-gerak-dan-tari-sebagai-saranaekspresi-dan-apresiasi-seni-bagi-anak-usia-dini/), diakses 17 Pebruari 2019. 